\title{
Food Security of Russia in Conditions of Western Sanctions
}

\author{
V.V. Moiseev \\ Shukhov Belgorod State Technological \\ University, 46 Kostyukova St., Russia, Belgorod, 308012, \\ din_prof@mail.ru \\ Zh.N. Avilova \\ Belgorod State University, Russia, 308015, Belgorod, \\ Pobedu str, 85 \\ janna-avilova@mail.ru
}

\author{
I.V. Kirova \\ Moscow Automobile and Road State Technical University \\ (MADI), Leningradsky Prospect, 64, 125319, Russia \\ kirovairina@yandex.ru \\ E.N. Parfenova \\ Belgorod State University, Russia, 308015, Belgorod, \\ Pobedu str, 85 \\ parfenova@bsu.edu.ru
}

\begin{abstract}
Regardless of the level of its political, socioeconomic development and the situation in the world, every state has to solve certain national problems, among them the problem of sustainable supply of the population with its own (domestic) food. To this end, it develops and strengthens its agro-industrial complex (AIC), which includes branches both for the production of agricultural products and for its processing.

Food security is considered one of the main objectives of the country's agricultural policy. However, the Russian Federation currently has an underdeveloped agro-industrial complex that is not able to ensure the country's food security or to solve the problem of reliable supply of the population with domestic food in accordance with approved medical norms and requirements. This becomes even more evident in the context of toughening of Western sanctions, when food becomes one of the main factors of political and economic pressure of economically developed countries against Russia, which is humiliating for it as a state that actually has one of the largest agrarian potentials in the world.
\end{abstract}

The article discusses the issues of ensuring the food security of our country, which come to the fore in connection with the expansion of economic sanctions by the US and the EU.

Keywords-food security, agro-industrial complex, problems of import substitution.

\section{INTRODUCTION}

To ensure food security in the new political and economic conditions caused by the tightening of anti-Russian sanctions, the state, combined with business, must take effective measures to develop the national agro-industrial complex, increase its own production of necessary food. It should be noted that in the development of the Russian agribusiness in the past few years there has been a positive trend. The production of food in Russia from 2011 to 2015 increased by 1.2 times. Being almost completely covered by the need of the domestic market regarding wheat (in 2017 the workers of the agro-industrial complex collected a record grain harvest during the entire history of the country - 134 million tons), and Russia became the world leader in its exports. The production of vegetable oil is annually growing by $10 \%$. $90 \%$ of the vegetable market is cornered by domestic goods. The production of poultry meat and pork is increasing. However, as practice has shown, the Russian agrarian and industrial complex can not yet independently meet the vital needs of the population for a number of reasons and ensure the country's food security to the full. Russia is in a rather difficult food situation today, which was negatively affected by the crisis phenomena of 2014-2016, the double denomination of the ruble, the rise in prices for food products.

Having vast arable land, of which 40 million hectares are still empty, Russia has a huge potential, realizing that the country can feed not only itself, but also a large part of the world population. However, at present the volume of agricultural production in Russia is less than modest: its share in gross value added in Russia is less than $4.5 \%$ (2016), insignificant growth was there in 2017, but its total annual volume was only 5.7 trillion rubles or about $\$ 100$ billion [1].

These and other circumstances require certain revision of the state's agrarian policy, reassessment of the previously adopted programs and projects for the development of the agro-industrial complex and its basic branch - agriculture. We need an objective analysis of the state and development of agro-industrial production and real measures to improve the work of the domestic agribusiness in the face of tightening of Western sanctions, as well as the food embargo imposed by the Russian Federation in response to Western sanctions.

President of Russia V.V. Putin, delivering a message to the Federal Assembly in December 2015 and targeting the political elite to achieve food security in the face of Western sanctions, set the task of the national level: to fully provide the domestic market with only domestic food by 2020 . "Not only can we feed ourselves with regard to our land, water, especially important resources," the national leader said, - but Russia is also able to become the world's largest supplier of healthy, environmentally friendly, high-quality food products 
that have long since disappeared from some Western producers, especially as the demand in the global market for such products is steadily growing. It is necessary to put into circulation millions of hectares of arable land, which are idle now ... "[2].

Three years later, the head of state again turned to the problem of food security. Announcing the next message to the Federal Assembly on March 1, 2018, V.V. Putin said, "Now we have to take the next step. Within four years, we are planning to deliver more food to the world markets than to import it into the country. At the same time, it is necessary to increase exports of meat products, high-value goods, and increase the country's self-sufficiency in beef, milk, vegetables "[3].

On May 7, 2018, the President signed the Decree "On National Purposes and Strategic Development Challenges of the Russian Federation until 2024", which instructed the government "to create a high-performance export-oriented sector in the basic sectors of the economy, primarily in the manufacturing and agro-industrial complex, developing on the basis of modern technologies and provided with highly qualified personnel "[4].

\section{PROBLEM STATEMENT}

To realize the goals and objectives in the field of ensuring the food security of the state, it is necessary to give the agroindustrial complex more attention from the political leadership, to increase the financing of agricultural and processing enterprises, to remove obstacles that impede their dynamic development. And most importantly: words should not disagree with the case, with real results in ensuring food security. In the next Presidential Address to the Federal Assembly, to which V.V. Putin spoke on March 1, 2018, marked a dramatic improvement in the situation with food in the country, reducing dependence on imports. "Back in the early 2000s, we seriously depended on the supply of imported food," V.V. Putin [3].

However, in providing Russians with food, there are no achievements that would indicate a "cardinal improvement in the food situation" or "a reduction in dependence on imports." Here are the facts: according to statistics, at present only 18 subjects of the Russian Federation are able to provide the population with minimal amounts of food products of their own production [5]. The leader among them was the Belgorod region, which, with a population of 1.541 million people, produces agricultural products in an amount sufficient to meet the minimum demand for food products of almost 4 million inhabitants. The share of the Belgorod region in the allRussian (of 85 regions of the Russian Federation) pork production is $14 \%$, and of poultry meat $-16.5 \%$. In the region, meat per capita is produced 9.4 times more than the national average. In terms of meat consumption per capita, it ranks first among Russian regions (325 kg per capita) [1]. The Krasnodar and Stavropol Territories, the Voronezh, Kursk and Tambov Regions can also provide the best food for their own production, but in the remaining regions of the Russian Federation, including the newly annexed Republic of Crimea, the agro-industrial complex is not able to provide citizens with sufficient quantities of own-produced food products.

To refute the statement of the speechwriters about "reducing dependence on imports," let us turn to the facts. During 13 years, from 2000 to 2013, the imports of foreign food products to Russia had grown 6 times higher than 2.6 trillion rubles [5]. According to the Federal Customs Service, imports to Russia from foreign countries alone increased by $27.1 \%$ to $\$ 89.833$ billion in January-June 2017 , compared to the same period one year before. In the import of food products, purchases of vegetables increased 1.7 times, cereals - by $40.5 \%$, dairy products - by $38.1 \%$, fruits - by $35 \%$, alcoholic and nonalcoholic products - by $31.7 \%$, vegetable oil - by $26.4 \%$, fish - by $22 \%$, meat and by-products - by $14.9 \%$, sugar - by $13.3 \%$ [7]. The situation regarding food imports for the first nine months of 2017 has not changed. Thus, the physical volumes of butter supply increased by $78.4 \%$, fresh and frozen fish - by $12.9 \%$, cheeses and cottage cheese - by $9.1 \%$, fresh and frozen meat - by $9 \%$, citrus fruits - by $5.4 \%$. During the same period, imports of food from the CIS increased by $2.6 \%$ in physical terms, including milk and cream - by $20.2 \%$, poultry - by $8.3 \%$, butter - by $1.2 \%$. So, in the group of food products and raw materials for their production, according to Russian customs, the imports of vegetables increased by $38.9 \%$, meat and offal products - by $18.1 \%$, fruits - by $16.0 \%$, dairy products - by $12,1 \%$ [8].

Thus, unfortunately, due to a number of reasons there has been no fundamental change in the dependence on imports, despite some separate positive trends in individual types of food products. The main reason for this situation is, in our opinion, is that today the Russian Federation has an underdeveloped agricultural sector, which is unable to ensure food security of the country, that is not yet able to consistently provide its own population with food on medical standards and requirements.

Many economists and political scientists argue that the current plight of Russian agriculture, the predominance of imports and food prices - a consequence of agricultural policy, carried out in the period of Yeltsin's reforms, insufficient financing of industries and agricultural enterprises. The result of these reforms was the massive bankruptcy of collective farms, the outflow of the active part of the labor force from the village, and the reduction of acreage by 41 million hectares. The average grain production per capita in Russia in 19901999 decreased more than 2 times, production of meat - 3 times, of milk - 1.5 times; the total volume of all agricultural products as a result of the Yeltsin reforms had decreased by $45 \%[5]$.

In early 2000, with the election of President V.V. Putin the attitude to the agrarian sector of the economy has definitely changed for the better. Since 2005, the state has been taking important steps to develop the agro-industrial complex: increased financing, supporting projects to produce its own food in every possible way. Significant contribution to the development of crops, livestock and other sectors of agriculture and processing of its products has encouraged the realization of the national project "Development of Agriculture" proposed by Russian President Vladimir Putin on 
September 5, 2005 in an Address to the government, parliament and regional governors. As it is known, this national project was aimed at the priority development of livestock, overcoming the demographic crisis in the industry, creating a modern competitive food production, stimulating the development of small forms of agribusiness. During the implementation, additional measures were included in the project, namely: state support for breeding livestock, sheep and goat breeding, reindeer herding and herd horse breeding, industrial fish farming.

The state allocated a little more than 19 billion rubles for the development of the agro-industrial complex in 2006, which amounted to $11 \%$ of the financial resources (186.8 billion rubles) allocated from federal sources for the implementation of all national projects in 2006. In 2007, the ratio to the agro-industrial complex had changed for the better. In addition, about 200 billion rubles were allocated for the development of domestic agriculture. This allowed to start the construction and modernization of 2,140 livestock complexes based on the most advanced technologies, which not only did not concede, but in some cases surpassed foreign analogues [9].

445 thousand loans worth 87 billion rubles were issued to private subsidiaries and farm enterprises, as well as agricultural consumer cooperatives, which is ten times more than in 2005. The average loan size for farmers was 1 million, for private farms - 135,000 rubles. Thanks to investments in 2007, the amount of tractors purchased by agricultural enterprises was more than 1.7 times higher than in 2005, and the number of combine harvesters and self-propelled harvesters had increased by 1.4 times [8].

Since 2008, the national project "Development of the AIC" has been transformed into the State Program for the Development of Agriculture for 2008-2012. To implement the program it was planned to allocate 551 billion rubles from the federal budget or 3 times more than in the previous five-year period. However, the amount of real government funding for this program was not sufficient for its implementation. The reason for it was the next financial and economic crisis, which occurred in 2008-2009.

Having summed up the disappointing results of its implementation, the Government of the Russian Federation approves the new State program for the development of agriculture and regulation of markets for agricultural products, raw materials and food for 2013-2020 by means of the Decree of July 12, 2012. The volume of planned budget financing of the agro-industrial complex was impressive: the amount of funds to be taken from the state budget was 187.864 billion rubles, in 2016 it was 258.140 billion and in 2020 it is supposed to approach 350.363 billion rubles [9]. There are certain doubts to be expressed about the issue that all the planned financial resources will indeed be allocated, but the fact itself that the state is trying to allocate more resources to the agro-industrial complex can not but rejoice. It is appropriate to note here that for modern Russia the inefficiency of public expenditures associated with the implementation of already planned programs is rather a typical feature. According to the recognition of the Prime Minister
D.A. Medvedev, almost half of the state targeted programs approved at the highest level are not being properly implemented.

As a result of the state program for the development of the agro-industrial complex, it is planned to increase the country's own food production to $85-95 \%$ by 2020 , depending on the category. These indicators practically corresponded to those boundaries that were established by the doctrine of food security of the Russian Federation, approved by the Decree of the President of Russia of January 30, 2010 [10].

The doctrine of food security of the Russian Federation was developed in order to implement the state economic policy in the field of ensuring food security aimed at the reliable supply of food to the population of the country, the development of domestic agro-industrial and fisheries complexes, prompt response to internal and external threats to the stability of the food market, effective participation in international cooperation in the field of food security.

The decree of the president approving the doctrine noted that the doctrine was a set of official views on the goals, objectives and main directions of state economic policy in the field of ensuring food security of the Russian Federation. According to the document, food security is one of the main directions of ensuring the national security of the country in the medium term, a factor of preserving its statehood and sovereignty, the most important component of the demographic policy, a prerequisite for the implementation of the strategic national priority: improving the quality of life of Russian citizens by guaranteeing high life standards. To assess the state of food security as a criterion, the share of domestic agricultural, fishery products and food in the total volume of commodity resources is to be determined [11].

The food security of the Russian Federation should be ensured within the legal space defined by federal legislation and legislation of the subjects of the Russian Federation. The preparation of the federal law on food security in Russia began in the mid-1990s. The discussion of this issue in governmental and scientific circles stimulated the development of normative and legal acts in this sphere. The first draft law "On Food Security of the Russian Federation", providing "legal bases for the economic impact of the state on agro-industrial production," was reviewed by the State Duma in December 1997, approved by the Federation Council, but was rejected by President Boris Yeltsin in January 1998. It was to legislate the guarantee for providing the population with food, requiring additional expenditures from the federal budget, which the state did not have and at that time and because of the difficult situation in the economy, these obligations could not be fulfilled properly. The next draft of the federal law "On Food Security of the Russian Federation" was considered by the State Duma but was not supported in the second reading on October 15, 2003 [12].

In 1999, the next Duma draft law "On Food Security of the Russian Federation" was submitted to the State Duma, according to the authors, taking into account the remarks of the previous similar draft law concerning additional expenditures from the budget of the Russian Federation. Due to these and other reasons, the new bill was mainly 
declarative, it did not fix the mechanism for solving the problem of food security and thus did not allow it to be provided. As a result, in 2005 it was rejected and withdrawn from further consideration.

In the absence of a special regulatory act, other laws were in effect in the country, to some extent related to ensuring food security, including: the Federal Law on the Development of Agriculture, the Federal Law on Procurement and Supply of Agricultural Products, Raw Materials and Foodstuffs for Federal Needs ", the Federal Law "On Food Quality and Safety", the Federal Law "On Sanitary and Epidemiological Well-Being of the Population", the Federal Law "On Veterinary Medicine", as well as other federal normative legal acts.

To date, a special law on food security of the country has not been adopted, and for the purposes of implementation in a number of republics, territories and regions, the laws of the subjects of the Russian Federation are in force. For example, the law "On Food Security of the Republic of Bashkortostan" No. 51 of 04.02.2000, the law "On Food Security of the City of Moscow" No. 39 of 12.07.2006 and others [13]. It seems to us that the federal law on food security of the Russian Federation has matured in a certain way. Its expediency is dictated by new geopolitical and internal circumstances.

Using the method of comparative analysis, we will try to compare the levels of food security in Russia and the United States. To do this, we use the following table.

TABLE I. PRODUCTION OF MAIN TYPES OF FOOD IN RUSSIA IN COMPARISON WITH THE UNITED STATES OF AMERICA*

\begin{tabular}{|c|c|c|c|}
\hline $\begin{array}{c}\text { Indicators (in } \\
\text { million tons) }\end{array}$ & Russia & USA & $\begin{array}{c}\text { Difference } \\
\text { in \% }\end{array}$ \\
\hline $\begin{array}{c}\text { Production of } \\
\text { milk }\end{array}$ & 31,1 & 91,3 & $293,6 \%$ \\
\hline $\begin{array}{c}\text { Production of } \\
\text { meat of livestock } \\
\text { and poultry }\end{array}$ & 9,9 & 42,6 & $-430,3 \%$ \\
\hline $\begin{array}{c}\text { Production of } \\
\text { grain }\end{array}$ & 134 & 465,9 & $-347,7 \%$ \\
\hline $\begin{array}{c}\text { Production of } \\
\text { potatoes }\end{array}$ & 31,1 & 20,0 & $+36,7 \%$ \\
\hline $\begin{array}{c}\text { Production of } \\
\text { fruits }\end{array}$ & 3,5 & 26 & $+742,8 \%$ \\
\hline
\end{tabular}

From the table it follows that for the production of basic types of food, Russia lags behind the United States in almost all positions several times. The exception is potatoes, which our country grows 1.5 times more than the United States. The biggest lag in own production is noticeable in meat (by $430.3 \%$ ), grain (by $347.7 \%$ ) and milk (by $293.6 \%$ ). In the US, there is the world's fourth largest livestock of cattle (95.848 million), giving meat and milk [14]. The third place in the world for cattle is China - 115.230 million, the second place is firmly held by India - 185 million, and the first place is occupied by Brazil, which has more than 207 million [14].

\footnotetext{
* The table was compiled by the authors on the materials of the open press
}

In Russia, as of January 1, 2018, according to the Federal State Statistics Service, the number of cattle on farms of all agricultural producers was 18.6 million heads, which is $0.6 \%$ below the indicator for the same date a year earlier. At the same time, the number of cows at the reporting date decreased by $0.7 \%$ to 8.2 million heads, sheep and goats - by $1.3 \%$, to 24.5 million heads. At the same time, the number of pigs increased by $5.7 \%$ - up to 23.3 million head, poultry - by $0.7 \%$, amounting to 556.6 million heads [15]

The problem of food security has already been solved for a long time in the USA. This country provides itself with basic food products for more than $100 \%$, and in certain industries, the United States of America are definitely the world leader. This country is currently the world leader in terms of both production and exports of agricultural products. The volume of production, sales and processing of agro-industrial products exceeds \$ 1.3 trillion [16].

The fundamental difference between our countries in ensuring food security: Russia imports $8.5 \%$ of food, and the US exports its food. In the achievement of Russian food security, a significant contribution can be made by the implementation of the planned state programs on import substitution in the agro-industrial complex with the goal of restoring the lost food independence of Russia, as well as providing Russians with high-quality food products of their own production. The solution of the task of import substitution is possible if the intensity of domestic agricultural production is increased based on the introduction of innovations and investments, as well as on the use of new and more productive technologies, and the development of the food and processing industries that form the agrifood market, food and economic security.

The state of food security is assessed by several criteria, including: physical and economic accessibility of food, food security and others. It is these criteria that create comfortable living conditions for citizens and are the determining factors in ensuring its national security of the state

Physical accessibility of food is the level of infrastructure development, which means that in every particular place of the country it is possible for the population to purchase food or catering in volumes and assortments that are not less than the established rational norms for food consumption. At present, the availability of the main resources of agricultural products and raw materials, the saturation of the Russian food market are on such a level that, in general, the physical availability of food is provided at a minimum (closer to average) level of consumption.

Economic accessibility of food is an opportunity to purchase food products at current prices in volumes and assortments that are not less than the established rational consumption norms, provided by the corresponding level of income of the population. Consumer demand and the level of consumption of food products per capita depend on the ratio of the growth rates of money incomes of the population and the prices of food products. Since the middle of the year 2001, the economic growth, and partly the state policy on income of the population, aimed at reducing poverty, ensured the growth of nominal incomes, wages and pensions, which outstripped 
the increase in food prices, which increased the availability of food for various social groups. However, it should be noted that for those 20 million Russians, who live according to official data under the poverty line, the economic accessibility of food is extremely low.

Food safety is a state of reasonable certainty that food products are not harmful to the health of the present and future generations.

Thus, to solve the problems associated with ensuring food security in the new political and economic conditions caused by the tightening of anti-Russian sanctions, it is necessary to modernize the agrarian policy of the Russian state and to develop the agro-industrial complex of Russia in every possible way.

\section{RESEARCH QUESTIONS}

In this study, the authors focus on the following problems:

1. Determination of the reasons for ensuring food security in Russia.

2. Analysis of the main directions of the state policy of ensuring Russia's food security in the conditions of Western sanctions.

\section{PURPOSE OF STUDY}

The aim of the study is to investigate the problems of ensuring food security through the agro-industrial complex and on this basis to offer recommendations for the implementation of planned programs in the context of Western sanctions.

\section{RESEARCH METHODS}

When studying the main aspects of the topic, the authors use the following methods: 1) an institutional method that allows one to analyze the role of the president, government, other authorities in implementing the state policy for ensuring food security; 2) a systematic approach that allows one to form a holistic and objective view of the state of the agroindustrial complex of Russia, to note both the positive aspects and the existing shortcomings in the implementation of the state policy for ensuring food security; 3) the method of comparative analysis used by the authors allows one to compare the level of food security in Russia and the United States; 4) the study has also used methods of content analysis, statistical and other methods of determining current trends in the implementation of the state policy of ensuring food security in the agro-industrial complex of Russia.

\section{FINDINGS}

1. Thus, in order to solve the problems of Russian food security in the new political and economic conditions caused by the next crisis and Western sanctions, there is a need for a radical review of the agrarian policy of the Russian state.

2. The reliable provision of Russian food security is a prerequisite for preserving the integrity and strengthening of the sovereignty of the Russian state, achieving food security, and successfully implementing a strategic national priority improving the quality of life of the population by universally guaranteeing high life standards, including the economic availability of food sufficient for an active and healthy lifestyle.

\section{THE CONCLUSION}

1. Western sanctions and embargo against the countries that imposed anti-Russian sanctions once again showed that Russia is not able to provide its citizens with all kinds of food on its own, even at a minimum level, not to mention balanced medical norms. It can not only grow the required volume of agricultural products, but also to process and preserve what the national agriculture produces. These and other circumstances require a thorough revision of the state's agrarian policy, the reassessment of previously adopted programs and projects for the development of the agroindustrial complex (APC) and its basic branch - agriculture.

2. In conclusion, it should be emphasized that both the state and the agribusiness should constantly improve their work in terms of food security of the country, especially in the conditions of anti-Russian sanctions and counter-forces, they should achieve the availability of food resources, in which food needs are mainly met by domestic production in sufficient amounts for normal vital activity of the population. Therefore, in order to solve the problems of food security of the Russian population, in addition to state support and stimulating the development of the national agrifood sector and measures to reduce poverty, it is necessary to develop and legislatively fix mechanisms for increasing the availability and quality of food, based on the goals of improving the nation's health.

3. The time and actions in this area of the new Russian government will show how measures will be taken to implement Russian President Vladimir Putin's decree of May 7, 2018, "On National Purposes and the Strategic Challenges of the Development of the Russian Federation until 2024".

\section{References}

[1] Agriculture of Russia. URL: http://ab-centre.ru/page/selskoehozyaystvo-rossii

[2] The President's, 2015, Address to the Federal Assembly. URL: http://kremlin.ru/events/president/news/50864

[3] The President's, 2018. Address to the Federal Assembly. URL: http://kremlin.ru/events/ president/news/56957

[4] The President signed the Decree "On national goals and strategic tasks of the development of the Russian Federation for the period until 2024". URL: http://kremlin.ru/events/president/news/57425

[5] S.N. Glagolev, V.V. Moiseev, Import substitution in the Russian economy, Belgorod: BSTU Publishing House, 276 p., 2015.

[6] Import of food products to Russia grew by $23.5 \%$. URL: http://agro2b.ru/ru/news/43321-Import-prodovolstvennyh-tovarovRossiyu-vyros.html

[7] V.V. Moiseev, "Actual problems of import subsumption in modern Russia”. Danish scientific journal, vol. 6, pp. 24-29, June 2017.

[8] S.N. Glagolev, V.V. Moiseev, "Import substitution as a factor in the development of Russia's agro-industrial complex printed", Bulletin of BSTU named after V.G. Shukhov, vol. 3. pp. 195-200, March 2016. 
[9] Strategy of development of food and processing industry until 2020. URL: https://gov.spb.ru/static/writable/ckeditor

[10] On the approval of the Doctrine of Food security of the Russian Federation. URL: http://pravo.gov.ru/proxy/ips/?docbody=\&first Doc $=1 \&$ lastDoc $=1 \&$ nd $=102135612$

[11] Chronicle of the meeting of the State Duma October 15, 2003. URL: http://api.duma.gov.ru/api/transcriptFull/2003-10-15

[12] S.N. Glagolev, V.V. Moiseev, Import substitution in the Russian economy, Belgorod: BSTU Publishing House, 276 p., 2015.
[13] Livestock of cattle in the countries of the world. URL: http://geo.1september.ru/article.php?ID=200701108

[14] By early 2018, the number of cattle in Russia decreased by $0.6 \%$. URL: http: //agrarii.com/k-nachalu-2018-goda-pogolove-krs-v-rossiisokratilos-na-0-6/ (circulation date is June 7, 2018).

[15] Features of livestock in the US . - URL: https://goferma.ru/zhivotnovodstvo/obshhie-dannye/zhivotnovodstvo-v-ssha.html (circulation date is June 7, 2018).

[16] V.V. Moiseev, "Actual problems of import subsumption in modern Russia”. Danish scientific journal, vol. 6, pp. 24-29, June 2017. 